\title{
ACRL and ARL to Sponsor Metcalf Research Project
}

ACRL and the Association of Research Libraries will co-sponsor a project supported by a grant of $\$ 73,365$ from the Council on Library Resources, Inc., for research leading toward the publication of a definitive book on the planning of college and university library buildings. Keyes D. Metcalf, librarian emeritus of Harvard University, will direct the project.

ALA will provide financial administration of the project. An advisory committee for it has been established with the following membership: Ralph Ellsworth, director of libraries, University of Colorado; William H. Jesse, director of libraries, University of Tennessee; Stephen A. McCarthy, director of libraries, Cornell University, and executive secretary of ARL; Frank B. Rogers, director, National Library of Medicine, Eileen Thornton, librarian, Oberlin College; and a representative of faculty interest in library building, to be designated. Richard Harwell will serve as liaison officer for the committee at ALA Headquarters. The committee held its first meeting in Chicago January 28.

In a news release from the Council on Library Resources announcing the project, William S. Dix, librarian of Princeton University and former executive secretary of ARL comments: "Despite the huge sums involved in construction and equipmenta single university library building may cost several to many millions of dollars to build and equip-there is at present no compilation which can provide the planners of library buildings with the vast fund of available information which should be brought to bear but which is now scattered. Each time a library is planned there is duplication of search for information on which planning decisions must be based, and there is no doubt that much relevant, significant information and recorded experience is often overlooked. It is anticipated that the book will significantly contribute to the effective planning of library buildings, to the avoidance of costly mistakes, and to the wiser and more effective use of funds."

Mr. Metcalf's manual will collect and synthesize the information available in the extensive but scattered literature of separate studies, records of library building institutes, and other reports. As director of the project, Mr. Metcalf will draw on the considerable amount of expert knowledge gained by certain librarians who have served as consultants for building projects. In addition, he will be aided by a small research staff and by a group of consultants comprised of architects, engineers, and other experts.

The book will begin with a discussion of the objectives of institutions and the manner in which these should influence architectural planning. Considerations of finance, public relations, and possible alternative methods of housing books will be described. Subsequent chapters will discuss selection of a building site, furniture and interior decoration, and other details, including such final problems as moving into a new building and maintenance costs. The book will be fully illustrated by drawings and photographs. Preparation is expected to take four years.

Mr. Metcalf has an outstanding record with respect to the planning of library buildings. He is in large part the deviser of the depository library and the undergraduate library. During his tenure at Harvard the Houghton and the Lamont libraries were erected there. He was active in the Cooperative Committee on Library Building Plans, called together by former President Harold W. Dodd of Princeton in 1944. This committee of university administrators, librarians, and architects gave impetus to a new concept of college library architecture. Mr. Metcalf has served as consultant for approximately fifty college library projects, including projects at McGill University, the University of Montreal, and the University of Baghdad, Iraq. 